\title{
PEMBERDAYAAN MASYARAKAT MELALUI PENGEMBANGAN DESA WISATA DENGAN KONSEP CBT (COMMUNITY BASED TOURISM) DI DESA LABUAN PANDAN
}

\author{
I GUSTI NGURAH ARYAWAN ASASANDI ${ }^{1)}$, MUHAMMAD AFZAL ${ }^{2)}$ \\ ${ }^{1)}$ Fak. Pertanian UNMAS Denpasar PSDKU Mataram, \\ ${ }^{2)}$ Fak.Hukum UNMAS Denpasar PSDKU Mataram \\ e-mail : ${ }^{1)}$ arya.sandi.as@gmail.com, ${ }^{2)}$ afzalalex369@gmail.com
}

\section{ABSTRAK}

Pariwisata merupakan salah satu sektor usaha yang menjanjikan, jika masyarakat setempat dapat melihat dengan baik potensi yang tersedia disekitar lingkungan tempat tinggal mereka. Dengan posisi negara Indonesia yang terletak pada jalur katulistiwa yang menyebabkan beragamnya jenis flora dan fauna, serta topografi kepulauan menyediakan hamparan pemandangan baik pesisir maupun keanekaragaman adat budaya yang tersedia, maka tidak heran jika peluang pariwisata masih terbuka sangat lebar untuk dapat dikembangkan. Desa Labuan Pandan merupakan desa pesisir dengan 2 (dua) gili yang ada di sebelah timur, sehingga menjadi magnet tersendiri bagi wisatawan yang ingin melihat langsung keindahan terumbu karang maupun ekosistem bakau (mangrove). Geliat pariwisata sudah mulai terlihat pada aktivitas para pegiat wisata yang bergabung dalam suatu komunitas yang dinamakan KOMPAK (Komunitas Pemuda Labuan Pandan Kreatif). Konsep CBT (Community Based Tourism) telah mulai dijalankan oleh komunitas KOMPAK ini sejak tahun 2017 dan tentunya sejak saat itu masyarakat yang ada di Desa Labuan Pandan terlibat dalam kegiatan wisata tersebut.

Penelitian ini bertujuan (1) Mengkaji proses pemberdayaan masyarakat lokal dengan konsep CBT (Community Based Tourism), (2) Kendala yang dihadapi masyarakat dalam melakukan kegiatan akivitas wisata dengan konsep CBT (Community Based Tourism) di Desa Labuan Pandan. Metode penelitian ini menggunakan metode deskriptif dengan pendekatan kualitatif, Data yang digunakan adalah primer dan skunder. Data Primer didapat dari wawancara dan observasi. Hasil Penelitian menunjukkan bahwa : (1) Kegiatan pemberdayaan masyarakat melalui wisata desa dengan konsep CBT (Community Based Tourism) berjalan dengan sangat baik. Hal ini ditunjukkan dari tingkat partisipasi masyarakat yang tinggi terhadap kegiatan - kegiatan wisata yang ada. Termasuk didalamnya menyiapkan akomodasi penginapan, kuliner, pertunjukan seni budaya dan ikut serta dalam kegiatan wisata pembelajaran alam (Educational Tourism), (2) Kendala yang dihadapi masyarakat yaitu, belum menguasai secara fasih bahasa asing, sehingga cukup menghambat dalam pertukaan informasi.

Kata kunci : Pemberdayaan, Desa Wisata, CBT (Community Based Tourism)

\section{ABSTRACT}

Tourism is one of the promising business sectors, if local people can see well the potential available around their neighborhood. With the position of the country of Indonesia which is located on the equator which causes diverse types of flora and fauna, as well as the archipelago's topography providing a stretch of both coastal and cultural diversity available, it is no wonder that tourism opportunities are still wide open to be developed. Labuan Pandan Village is a coastal village with 2 (two) dykes in the east, so that it becomes a magnet for tourists who want to see first hand the beauty of coral reefs and mangrove ecosystems. Tourism stretching has begun to be seen in the activity of tourism activists who joined a community called KOMPAK (Labuan Pandan Kreatif Youth Community). The concept of CBT (Community Based Tourism) has been started by the KOMPAK community since 2017 and of course since then the people in Labuan Pandan Village are involved in the tour activities.

This study aims (1) To examine the process of empowering local communities with the concept of CBT (Community Based Tourism), (2) Constraints faced by the community in conducting tourism activities with the concept of CBT (Community Based Tourism) in Labuan Pandan Village. This research method uses 
descriptive method with a qualitative approach; the data used are primary and secondary. Primary data obtained from interviews and observations. The results showed that: (1) Community empowerment activities through village tourism with the concept of CBT (Community Based Tourism) went very well. This is indicated by the high level of community participation in existing tourism activities. This includes preparing accommodation, culinary, cultural arts performances and participating in educational learning activities (Educational Tourism), (2) Constraints faced by the community, that is, they have not mastered fluent foreign languages, so that they are quite inhibiting information disclosure.

Keywords: Empowerment, Tourism Village, CBT (Community Based Tourism)

\section{PENDAHULUAN}

\section{Latar Belakang}

Indonesia adalah negara besar yang memiliki beragam suku, adat, dan budaya yang berbeda-beda. Selain itu juga, dengan posisi negara Indonesia yang berada dijalur garis katulistiwa maka menyebabkan beragamnya flora dan fauna yang tersebar diseluruh pelosok negeri. Potensi kekayaan alam yang melimpah ruah terbentang dari sabang sampai merauke dan dari Miangas sampai Pulau Rote sangat dapat dikembangkan untuk pengembangan sektor wisata. Menurut data pada Bulan Januari sampai Maret tahun 2019 saja jumlah wisatawan asing yang datang berjumlah 3.815.283 (Tiga Juta Delapan Ratus Lima Belas Ribu Dua Ratus Delapan puluh Tiga) Orang (Kemenpar, 2019). Angka tersebut cukup besar dan jika desadesa di Indonesia dapat menangkap peluang tersebut maka akan sangat mungkin dapat mengurangi angka kemiskinan di desa.

Desa Labuan Pandan merupakan salah satu desa yang masuk dalam wilayah administratif Kecamatan Sambelia Kabupaten Lombok Timur Provinsi Nusa Tenggara Barat. Berada di ujung timur Pulau Lombok dan terdapat 3 (tiga) gili yang ada disebelah timur, yaitu Gili Petagan, Bidara dan Kondo. Desa Labuan Pandan merupakan desa dataran rendah yang sangat dekat dengan bibir pantai, dengan curah hujan yang sedang setiap tahunnya. Bencana gempa yang terjadi pada tanggal 19 Agustus 2018 berkekuatan 6,9 Magnitudo, telah membuat kerusakan pada fasilitas umum pedesaan maupun perumahan warga. Pada saat itu banyak masyarakat yang tinggal di tenda-tenda pengungsian dan juga kekurangan air bersih serta sembako.

Kegiatan pariwisata berbasis masyarakat atau yang disebut sebagai pariwisata dengan konsep CBT (Community Based Tourism) merupakan salah satu terobosan yang sangat tepat paska kejadian bencana gempa. Kegiatan ini diinisasi oleh KOMPAK (Komunitas Pemuda Kreatif Labuan Pandan) yang anggotanya merupakan pemuda dan pemudi asli Desa Labuan Pandan, program kerja KOMPAK pada awalnya adalah ingin merubah pemuda desa yang awalnya kurang melakukan kegiatan produktif menjadi lebih produktif lagi. Namun sejak tahun 2017 sampai sekarang kegiatan KOMPAK telah bertambah yaitu mengelola wisata berbasis masyarakat, berkat kerjasama yang telah dilakukan dengan agen travel yang beroperasi di wilayah sembalun. Sejak 3 (tiga) tahun berjalan jatuh bangun KOMPAK rasakan, ditambah dengan bencana gempa yang terjadi pada tahun 2018 lalu, namun tidak menyurutkan kegiatan wisata yang ditawarkan.

Kegiatan wisata berbasis masyarakat yang telah berjalan selama 3 (tiga) tahun, dijalankan oleh KOMPAK, telah cukup banyak membawa dampak sosial maupun ekonomi masyarakat di Desa Labuan Pandan. Namun ada beberapa hal yang perlu perhatkan terutama pada aspek pemberdayaan masyarakat. Dikarenakan masyarkat merupakan pihak yang paling mementukan keberlanjutan sebuah kegiatan. Menurut Hadi (2009) Pendekatan utama dalam konsep pemberdayaan adalah bahwa masyarakat tidak dijadikan objek dari berbagai proyek pembangunan, tetapi merupakan subjek dari upaya pembangunannya sendiri. Oleh karena itu, kegiatan wisata berbasis masyarakat atau CBT (Comunnity Based Tourism) di Desa Labuan Pandan perlu dilihat dari segi aspek pemberdayaan bagi masyarakat sekitar.

\section{Tujuan Penelitian}

Adapun tujuan dari penelitian ini antara lain :

1. Untuk mengetahui sejauh mana pemberdayaan masyarakat yang telah terbangun dari kegiatan Desa Wisata dengan konsep CBT (Community Based Tourism) yang dikembangkan oleh KOMPAK?

2. Untuk mengetahui kendala yang dihadapi oleh masyarakat ketika menyelenggarakan kegiatan wisata desa berbasis masyarakat atau CBT (Community Based Tourism). 


\section{METODE PENELITIAN}

Metode dalam penelitian ini adalah metode deskriptif. Menurut Nawawi (2006) metode deskriptif dapat diartikan sebagai prosedur atau cara memecahkan masalah penelitian dengan memaparkan keadaan obyek yang diselidiki sebagaimana adanya, berdasarkan fakta - fakta yang aktual pada saat sekarang. Data yang digunakan dalam penelitian ini adalah data primer dan sekunder. Data primer diperoleh dari wawancara langsung dengan responden yaitu Ketua lembaga KOMPAK dan juga masyarakat yang terlibat langsung dalam kegiatan pariwisata dengan konsep CBT (Comunnity Based Tourism). Sedangkan data sekunder diperoleh dari buku, laporan dari pemerintah, jurnal - jurnal, website dan data dokumen yang ada di pemerintah desa.

Lokasi penelitian dipilih secara Perposive Sampling dengan dasar bahwa di Desa Labuan Pandan telah melaksanakan kegiatan wisata dengan konsep CBT (Comunnity Based Tourism). Data diperoleh dengan menggunakan teknik observasi baik pada lokasi maupun observasi ke lembaga KOMPAK dan masyarakat dengan dipandu oleh kuisioner.

\section{HASIL DAN PEMBAHASAN}

\section{Kegiatan Wisata yang berbasis CBT (Comunnity Based Tourism)}

Kegiatan pariwisata yang menggunakan konsep CBT (Comunnity Based Tourism) di Desa Labuan Pandan dimulai pada tahun 2017. KOMPAK (Komunitas Pemuda Labuan Pandan Kreatif) merupakan sebuah komunitas yang didirikan oleh anak-anak muda yang berasal dari Desa Labuan Pandan. Pada awalnya KOMPAK bergerak dibidang pemberdayaan pemuda dibidang sosial dan lingkungan. Setelah menjalin kerjasama dengan pihak biro perjalanan wisata (travel) maka disepakati KOMPAK terlibat dalam paket perjalanan wisata, khususnya wisata edukasi. Sejak dibentuknya lembaga KOMPAK ini yaitu tahun 2017 telah memfasilitasi 3 (tiga) kali paket wisata edukasi hingga tahun 2019. Pada tahun 2017 KOMPAK memfasilitasi 24 (dua puluh empat) orang wisatawan asing yang berasal dari Negara Singapura. Wisatawan asing tersebut tinggal selama 9 (sembilan) hari di Desa Labuan Pandan. Adapun kegiatan para wisatawan asing tersebut yaitu Transplantasi terumbu karang, penanaman bakau (mangrove), mengajar bahasa inggris kepada anak-anak SD (sekolah dasar), pelatihan pendidikan bahasa inggris untuk masyarakat lokal, pengenalan budaya seperti cilokaq (salah satu kesenian musik dari adat sasak), pelatihan membuat minyak kelapa serta belajar bagaimana kehidupan masyarakat lokal Desa Labuan Pandan dengan tinggal bersama masyarakat dan mengikuti kegiatan sehari-hari masyarakat.

Pada Tahun 2018 KOMPAK juga menerima wisatawan asing dari Singapura. Rata-rata wisatawan asing tersebut berprofesi sebagai mahasiswa. Kegiatan wisata yang dijalankan yaitu transplantasi terumbu karang, penanaman bakau (mangrove), mengajar bahasa inggris di sekolah SD (Sekolah Dasar), serta mengajarkan bahasa inggris bagi penduduk lokal. Selain itu juga wisatawan asing tersebut mempelajari juga tentang adat budaya serta mempraktekkan kegiatan sehari-hari masyarakat. Jumlah wisatawan yang hadir berjumlah 18 (delapan belas) orang dan tinggal selama 7 (tujuh) hari di rumah-rumah masyarakat. Sedangkan pada tahun 2019 terdapat 11 (sebelas) orang wisartawan asing yang mengunjungi Desa Labuan Pandan. Ke sebelas wisatawan tersebut merupakan mahasiswa dari Singapore University Of Social Science (SUSS). Lama tinggal di Desa Labuan Pandan yaitu 10 (sepuluh) hari dengan beberapa agenda kegiatan yang bermanfaat. Kegiatan wisatawan hampir sama dengan kegiatan pada tahun 2017 dan 2018, namun perbedaannya adalah adanya penambahan kegiatan seperti pembuatan makanan tradisional yaitu sayur ares, membuat minyak kelapa dan yang lainnya.

\section{Pemberdayaan Masyarakat}

Menurut teori pemberdayaan masyarakat sendiri merupakan suatu upaya atau kiat dalam membawa masyarakat kedalam suatu keadaan yang lebih baik dengan menggunakan seluruh potensi yang mereka miliki. Jadi, untuk dapat melihat proses pemberdayaan yang terjadi pada masyarakat Desa Labuan Pandan, akibat dari adanya kegiatan wisata yang di fasilitasi oleh lembaga KOMPAK ini maka perlu adanya variabelvariabel pengukurannya. Beberapa variabel pengukuran yang digunakan dalam mengkaji pemberdayaan masyarakat dalam kasus penelitian ini yaitu; (1) Peningkatan Ekonomi, (2) Sosial, (3) Budaya, (4) Lingkungan, dan (5) Kesadaran Politik. 


\section{a.Peningkatan Ekonomi}

Dalam kegiatan wisata berbasis CBT (Community Based Tourism) ini, banyak memberikan manfaat ekonomi secara langsung kepada masyarakat. Manfaat secara ekonomi ini didapat dari sewa rumah (akomodasi) dan ongkos pembelian bahan makanan yang akan disajikan kepada wisatawan asing yang tinggal di masing-masing rumah warga. Dari tahun 2017 hingga 2019 sudah 15 (lima belas) rumah yang disewa untuk jasa penginapan para wisatawan asing. Secara ekonomi Masyarakat Desa Labuan Pandan sangat merasakan manfaatnya, dari 15 (lima belas) rumah tersebut menggunakan sistem sewa dengan biaya Rp.100.000,- (seratus ribu rupiah) per malam. Sedangkan untuk biaya konsumsi, pemilik rumah mendapatkan Rp.25.000,- (dua puluh lima ribu rupiah) per sekali makan, dan untuk 1 (satu) hari ada 3 (tiga) kali makan. Jadi, total yang diterima pemilik rumah adalah Rp.175.000,- (seratus tujuh puluh lima ribu rupiah) per hari. Dalam hal penambahan lapangan kerja, banyak pemuda yang tergabung dalam lembaga KOMPAK yang sekaligus menjadi EO (Event Organizer) dari kegiatan wisata ini, sehingga secara otomatis menambah lapangan pekerjaan. Menurut Suansri (2003) Aspek peningkatan ekonomi dalam kegiatan wisata berbasis CBT (Community Based Tourism) adalah menghasilkan pendapatan (income) bagi masyarakat dan menambah lapangan kerja. Maka, dalam hal ini kegiatan wisata berbasis CBT (Community Based Tourism) di Desa Labuan Pandan pada aspek yang perama yaitu aspek ekonomi telah tercapai adanya suatu peningkatan ekonomi.

\section{b. Dimensi Sosial}

Menurut Suansri (2003) aspek sosial meliputi (1) Peningkatan kualitas hidup, (2) Mempromosikan kebanggan komunitas, (3) Membangun manajemen organisasi. Setelah dilakukan kajian mendalam kepada responden, untuk indikator pertama yaitu Peningkatan kualitas hidup bahwa telah terjadi peningkatan kualitas hidup pada masyarakat sasaran. Jenis kualitas hidup yang meningkat adalah dalam bidang kebersihan perumahan dan pola hidup sehat, menurut Stiglitz dalam Mahmudah (2015) menyebutkan ada beberapa bidang yang terkait dengan kualitas hidup, diantaranya yaitu : Kesehatan, pendidikan, aktivitas personal, hak suara politik dan tata kelola pemerintahan, koneksi sosial, kondisi lingkungan dan ketidakamanan pribadi. Sedangkan dalam kegiatan wisata berbasis CBT (Community Based Tourism) di Desa Labuan Pandan, telah terjadi peningkatan kualitas hidup. Pada aspek kesehatan, kebersihan meningkat disekitar rumah penduduk tempat wisatawan menginap, selain itu juga pola hidup bersih telah diterapkan oleh masyarakat agar wisatawan betah tinggal dirumah tersebut. Aspek kedua yaitu mempromosikan kebanggan komunitas, dalam hal ini masyarakat yang terlibat dalam kegiatan wisata berbasis CBT (Community Based Tourism) di Desa Labuan Pandan, telah melaksanakan kegiatan mempromosikan kebanggaan komunitas yakni kegiatan seni gendang beleq. Pertunjukkan seni ini diperuntukkan untuk menyambut wisatawan yang baru tiba di Desa Labuan Pandan. Aspek ketiga yaitu membangun manajemen organisasi, setelah melakukan wawancara kepada responden bahwa manajemen organisasi sudah tercipta pada lembaga KOMPAK. Sebagai suatu organisasi yang bergerak pada isu wisata dan lingkungan maka dalam pelaksanaannya tentunya diperlukan sebuah manajemen organisasi yang baik, hal ini ditandai dari bagaimana menyelesaikan masalah internal organisasi dan menjalankan kegiatan wisata edukasi.

\section{c. Dimensi Budaya}

Dimensi budaya yang tersentuh pada kegiatan wisata berbasis CBT (Community Based Tourism) di Desa Labuan Pandan yaitu wisatawan asing mengikuti kegiatan sehari-hari masyarakat desa. Seperti, ikut memasak masakan sehari-hari, mencari pakan ternak, membuat minyak kelapa, dan lain sebagainya. Hal-hal tersebut menjadi sebuah paket wisata yang dijual dan dapat menambah penghasilan masyarakat desa. Aspek kedua adalah menanamkan pengembangan dalam budaya alami, yang dimana pada kegiatan wisata berbasis CBT (Community Based Tourism) di Desa Labuan Pandan telah menanamkan budaya secara alami dengan cara memperagakan langsung didepan wisatawan pada saat wisatawan tinggal dirumah warga. Beberapa contoh budaya yang ditanamkan secara alami adalah bagaimana adab ketika makan bersama, budaya gotong royong, budaya dalam menghormati orang tua dan lain sebagainya.

\section{d. Dimensi Lingkungan}

Dalam melihat pemberdayaan yang terjadi pada dimensi lingkungan, maka dapat dilihat dari 3 (tiga) aspek yaitu (1) Mempelajari daya dukung daerah sekitar, (2) Mengelola limbah buang, dan (3) mengingatkan kesadaran konservasi. Aspek pertama yaitu mempelajari daya dukung daerah sekitar telah dilaksakan oleh wisatawan asing tersebut. Pada kunjungan tahun 2017, 2018 dan 2019 kegiatan wisatawan juga termasuk mempelajari daya dukung daerah sekitar, dengan melakukan kegiatan berjalan mengelilingi lingkungan sekitar Desa Labuan Pandan. Selain itu juga kegiatan yang tidak kalah penting adalah memotret sumber daya alam maupun sumber daya manusia pada minggu pertama di setiap kedatangan wisatawan. Aspek yang 
kedua adalah mengelola limbah buang, pada setiap kunjungan wisatawan ke Desa Labuan Pandan maka selalu dikunjungi sentra pengrajin limbah plastik. Limbah plastik diolah menjadi tikar plastik, gorden dan tas dari plastik bekas. Aspek ketiga yaitu mengingatkan kesadaran konservasi, dalam kegiatan wisata berbasis CBT (Community Based Tourism) di Desa Labuan Pandan salah satu paket wisata yang menarik bagi wisatawan adalah menanam bibit bakau (mangrove) di Gili Petagan. Secara tidak langsung dapat mengajarkan masyarakat sekitar untuk selalu memperhatikan alam disekitar mereka. Selain menanam bakau (Mangrove) wisatawan juga melakukan transplantasi terumbu karang disekitar Gili Petagan.

\section{e. Dimensi Politik}

Dalam ilmu pemberdayaan dimensi politik menjadi penting, karena mampu membawa masyarakat ke arah sebuah perubahan yang lebih cepat. Dibandingkan jika proses pemberdayaan tanpa dibarengi oleh kekuatan politik maka daya saing tidak cukup kuat dan lambat untuk berubah kearah yang lebih baik. Aspek pertama yaitu partisipasi masyarakat setempat, selama 3 (tiga) tahun ini banyak perubahan yang muncul dalam kehidupan masyarakat Desa Labuan Pandan, khususnya dalam hal antusias dalam menerima tamu atau wisatawan yang berkunjung. Pada awalnya kedatangan wisatawan masih dianggap hal yang tidak biasa oleh masyarakat, terutama ketika dibutuhkan rumah masyarakat untuk tempat tinggal wisatawan. Cukup sulit mencari rumah yang bersedia untuk ditinggali wisatawan, dikarenakan ada beberapa hal yang menjadi kendala yaitu, masalah bahasa yang membuat masyarakat tidak percaya diri dalam menerima wisatawan asing dirumahnya. Selain itu juga masalah kebersihan yang dimana menjadi hal yang cukup mengganggu rasa percaya diri masyarakat untuk menerima wisatawan asing. Namun kini banyak masyarakat yang menawarkan diri agar rumahnya ditinggali oleh wisatawan asing, selain dapat bercengkrama tentunya agar mendapatkan penghasilan tambahan dari sewa rumah dan konsumsi. Aspek kedua adalah meningkatkan kemampuan komunitas ke luar, dalam hal ini Komunitas KOMPAK yang merupakan komunitas lokal penyelenggara dari kegiatan wisata berbasis CBT (Community Based Tourism) di Desa Labuan Pandan telah meningkat kemampuan awal dari yang tertutup menjadi terbuka. Hal ini ditunjukkan oleh beberapa kerjasama yang telah dan akan disepakati, beberapa kerjasama yang dimaksud yaitu kerjasama dalam bidang tourism dengan travel internasional. Selain itu juga kerjasama dengan beberapa lembaga donor untuk membantu recovery dan pembangunan sarana ibadah maupun rumah penduduk yang hancur akibat gempa. Kerjasama tersebut menghasilkan bantuan untuk masjid di Dusun Labuan Pandan Induk sebesar Rp.10.000.000,- (Sepuluh Juta Rupiah), Pembangunan Musholla sebesar Rp.30.000.000,- (Tiga Puluh Juta Rupiah), Bantuan korban gempa untuk Desa Obel-obel sebesar Rp.35.000.000,- (Tiga Puluh Lima Juta Rupiah) dan untuk Desa Labuan Pandan sekitar Rp.80.000.000,- (Delapan Puluh Juta Rupiah) yang diperuntukkan untuk huntara (Hunian Sementara) dan pemberian sembako (Sembilan Bahan Pokok). Aspek ketiga adalah memastikan hak dalam pengelolaan sumber daya alam, selama Komuitas KOMPAK menjalankan kegiatannya sebagai penyelenggara kegiatan wisata berbasis CBT (Community Based Tourism) di Desa Labuan Pandan, tidak ada pihak yang menghalangi dalam mengakses sumberdaya, baik gili, laut dan sosial kemasyarakatan. Semua aktifitas dapat berjalan dengan lancar bahkan sangat didukung oleh Pemerintah desa dan kecamatan setempat.

\section{Kendala -kendala}

Adapun kendala yang dihadapi masyarakat ketika menjalani kegiatan wisata berbasis masyarakat atau CBT (Comunnity Based Tourism) di Desa Labuan Pandan, yaitu belum menguasai secara fasih bahasa asing, sehingga cukup menghambat dalam pertukaan informasi. Secara umum pertukaran informasi masih menggunakan jasa penerjemah yang berasal dari pemuda KOMPAK.

\section{SIMPULAN DAN SARAN}

\section{Simpulan}

Adapun simpulan yang dapat ditarik dari penilitian ini yaitu :

1. Kegiatan pemberdayaan masyarakat melalui wisata desa dengan konsep CBT (Community Based Tourism) berjalan dengan sangat baik. Hal ini ditunjukkan dari tingkat partisipasi masyarakat yang tinggi terhadap kegiatan - kegiatan wisata yang ada. Termasuk didalamnya menyiapkan akomodasi penginapan, kuliner, pertunjukan seni budaya dan ikut serta dalam kegiatan wisata pembelajaran alam (Educational Tourism).

2. Kendala yang dihadapi masyarakat yaitu, belum menguasai secara fasih bahasa asing, sehingga cukup menghambat dalam pertukaan informasi. 


\section{Saran-saran}

Perlu kiranya untuk dapat terus ditingkatkan kemampuan bahasa inggris kepada masyarakat khususnya yang rumahnya disewakan untuk wisatawan asing.

\section{DAFTAR PUSTAKA}

Hadi,AP.2009. Konsep Pemberdayaan, Partisipasi dan Kelembagaan Dalam Pembangunan. Yayasan Agribisnis/Pusat Pengembangan Masyarakat Agikarya (PPMA). Jakarta.

Kartasasmitha, Ginandjar. 1996. Pembangunan untuk Rakyat: Memadukan Pertumbuhan dan Pemerataan. PT. Pusaka Cisendo. Jakarta.

Kemenpar, 2019. Data Kunjungan Wisatawan Mancanegara Bulanan Tahun 2019 (Januari-Maret Tahun 2019). Tanggal Akses : 05 Mei 2019. Pukul : 12:29. Alamat Url : http://www.kemenpar.go.id/post/data-kunjungan-wisatawan-mancanegara-bulanan-tahun-2019januari-maret-tahun-2019.

Mahmudah, Henny. 2015. Analisis Etos Kerja Pemulung Dalam Meningkatkan Kualitas Hidup di Kecamatan Tikung Lamongan (Studi Pemulung Muslim di Desa Jatirejo Kecamatan Tingkug Lamongan). Pasca sarjana Fakultas Ekonomi dan Bisnis Universitas Brawijaya. Malang.

Nawawi, H. Hadari. 2006. Instrumen Penelitian Bidang Sosial. Gadjah Mada University Press. Yogyakarta.

Republik Indonesia. 2010. Undang - Undang Nomor 10 tahun 2009 tentang Kepariwisataan. Lembaran Negara Republik Indonesia Nomor 4966. Jakarta.

Soemarno, 2010. Desa Wisata. Alamat URL : marno.lecture.ub.ac.id/files/2012/01/Desa-wisata.doc Tanggal Akses 12 Juni 2019. Pukul : 19.02.

Suansri, Potjana. 2003. Community Based Tourism Handbook. Mild Publishing. REST Project. Thailand.

Zubaedi. 2007. Wacana Pembangunan Alternatif : Ragam Perspektif Pembangunan dan Pemberdayaan Masyarakat. Ar Ruzz Media. Jakarta. 